\title{
Healthy and Active Ageing: The role of social capital in health promotion
}

\author{
Abstract \\ Objectives: This paper examines the context of health promotion actions that are focused \\ on/contributing to strengthening social capital by increasing community participation, \\ reciprocal trust and support as the means to achieve better health and more active ageing. \\ Method: The methodology employed were a literature review/research synthesis, and a \\ thematic analysis. \\ Results: Four core themes emerged from the analysis: a) active ageing; b) the relationship \\ between social capital and ageing; c) the importance of social capital in health promotion; and \\ d) policy implications. The role of social capital in health promotion stresses empowerment, \\ intergenerational support, the building of social trust, and the need to tackle loneliness among \\ older adults. The importance of community/social participation emerged from the literature \\ review as a key contributor to the maintenance and promotion of a healthier ageing \\ population. \\ Conclusion: Supporting long-term social capital building within communities can lead to \\ improved public health and well-being for an ageing population.
}

\section{Keywords}

Healthy ageing; Active ageing; Social capital; Trust; Networks; Older adults. 


\section{Introduction}

There has been a rapid increase in the global ageing population of 2.6 per cent per year. By 2045 it is expected to exceed the child population, particularly in developed countries. By 2050 nearly one third of the global population is expected to be above the age of 60 years. ${ }^{1}$ The United Nations (UN) therefore has therefore stressed that further knowledge is needed to assist policy-makers in making the necessary policy changes to tackle the economic and social challenges arising from population ageing. ${ }^{1}$ The present paper focuses on the ways in which healthy and active ageing can be facilitated through health promotion interventions explicitly organised around the concept of social capital.

According to the World Health Organization (WHO), health promotion aims to influence the determinants of health with the aim of improving population health, reducing health inequalities, endorsing human rights and building social capital. ${ }^{2}$ As stated in the Ottawa Charter for Health Promotion ${ }^{3}$ two of the core health promotion actions are: (a) the creation of supportive environments, and (b) the strengthening of community actions. Both actions adopt a socio-ecological approach, and are based on equity and the enhancement of social support, participation, and empowerment of the individual towards health issues. ${ }^{3}$ In addition, WHO considers participation to be one of the three pillars - along with health and security - for building policies towards active ageing ${ }^{4}$. Community empowerment is an essential element of any health promotion initiative ${ }^{5}$. Participation and trust are core concepts of the notion of social capital that relate to community empowerment ${ }^{6}$. According to Howard et al. ${ }^{7}$, links exist between health outcomes, social capital and health promotion actions for social change. In terms of health outcomes and health promotion, social capital can be used as a means for promoting health and wellbeing through social change and the fairer allocation of resources. If social capital is built in a substantive way among ageing populations, then this may potentially have a major impact ${ }^{8}$. Against this background, the overall aim of this paper is to examine the context of health promotion actions focused on/contributing to the strengthening social capital by increasing community participation, reciprocal trust and support, as the means to achieve better health and more active ageing among populations. The specific research questions underpinning the present study were:

a) What is already known about the implementation of social capital for promoting healthy ageing?

b) How can social capital contribute to future health promotion policies and practices that aim for healthier and more active ageing populations?

\section{Background}

According to WHO's definition, health is "a state of complete physical, mental and social wellbeing and not merely the absence of disease or infirmity". "According to the definition of healthy ageing employed in the present paper, healthy ageing is the process of adapting and compensating for the decline of physical and cognitive health, with the aim of a person 
achieving the best possible levels of function and participation (physical, social, etc.) in his or her everyday life. ${ }^{10}$ The UN recognises that there is correlation between disability and ageing. According to a 2003 report, 63 per cent of persons with disabilities were above the age of $45^{11}$.

Although the 'settings approach' for health promotion - implemented in schools, workplaces, healthcare facilities, and clinical and/or community settings - has been enthusiastically supported for many years by health promotion practitioners ${ }^{12}$, it has been claimed to rest on shaky social scientific foundations. The latter views settings as something more than just 'vessels', arguing instead for the use of an ecological and critical approach to settings for health promotion ${ }^{13}$. Applying an ecological approach to health promotion through a 'settings approach' may ensure prolonged health benefits for older people, since it may reduce the density of chronic diseases into a shorter period of time, and improve individuals' overall quality of life ${ }^{14}$. A settings approach to a community of older persons may also challenge prejudicial perceptions of older people as being burden to the economy and society, and move towards viewing older persons as respectful and valuable members of the community ${ }^{14}$.

The major theorists of social capital include Bourdieu, Coleman and Putnam, who, although viewing social capital from different perspectives, all agree that social networks are (i) key contributors to social capital, and (ii) can lead to cooperation with positive outcomes. Bourdieu ${ }^{15}$ specifically views social capital as the collective of resources which associate with persons' networks of formal or informal relationships. For Coleman, social capital encompasses prospects of reciprocity, trust, shared values, norms and obligations ${ }^{16}$. According to Putnam ${ }^{6}$, social capital may be defined as a public good comprising trust, ties and norms, and as a 'moral resource' which, unlike other types of capital (human, financial, etc), is not the private property of individuals and is based on social activities.

Although the theoretical boundaries of the notion of social capital are still under discussion, it can provide a means for organising and planning community health promotion ${ }^{17}$. Social capital offers a different lens for viewing community health partnerships, and may also offer a framework for the evaluation of the processes and effectiveness of community interventions ${ }^{18}$. While some have seen a risk of enhancing social inequalities through the implementation of social capital-based health promotion initiatives, ${ }^{19}$ a recent systematic review of studies published between 1990 and 2011 found positive associations between elements of social capital and aspects of mental well-being among older adults. ${ }^{20}$

\section{Methods}

Scientific journals were searched to find articles that explored issues relevant to ageing, social capital and health promotion. Online sources were searched, and in particular, the following fifteen electronic sources were accessed: Pubmed; Elsevier ScienceDirect; BMJ Journals Online; ISI Web of Knowledge [v.4.10] (including SCI-EXPANDED, SSCI, A\&HCI); SAGE Journals online; ProQuest; The Cochrane Library; Blackwell-Wiley; ASSIA; Oxford Journals; Expanded Academic ASAP; Emerald; SpringerLink; JSTOR; and Cambridge Journals Online.

The inclusion criteria adopted for the electronic literature search were: articles that in their abstract/title included the keywords "health" AND "promotion" AND "social" AND 
"capital" AND "ag(e)ing"; articles published between January 2001 and March 2011 in the English language; only articles published in scientific journals (commentaries, reviews and original research); and with an abstract in which there was information relevant to the research questions of the present study. During the search, editorials and letters were excluded. During the initial screening process of articles, all titles and abstracts were examined and ones that did not meet the abovementioned criteria were excluded.

The literature review/research synthesis on the content of papers employed thematic analysis. The full text of included papers was read and text segments, in the form of phrases or paragraphs relevant to and matching (fully or partially) the objectives of the present study, were extracted. The meaning of each of these text segments was classified by theme. Latentlevel analysis was conducted according to which text segments were allocated to themes on the basis of the dominant meaningful concept within them ${ }^{21}$. For example, a text segment referring to "the use of the reminiscence method in research of focus groups of older adults and young persons" was fitted under the theme of "Intergenerational support/interaction" which describes the main features of the text segment, despite the fact that the exact words of the theme chosen were not found in this passage. The core themes presented were not predetermined but emerged inductively in the course of the analysis through a bottom-up approach.

\section{Results}

The online search yielded 26 citations of which only six were eligible for inclusion in the analysis (Figure 1). Table 1 presents information on the six articles included regarding their objectives, methods of data collection, sample and context, social capital indicators used, and health promotion activities reported on.

'Figure 1' about here

'Table 1' about here

In total, seventeen themes were identified. These were further grouped into four core themes as shown in Table 2.

\section{'Table 2' about here}

\section{Core Theme 1: Active Ageing}

Defining active ageing. Active ageing refers to the process of empowering older adults towards self-actualisation, self-confidence, and independent and dignified living, based on one's own personal values as well as being able to stand up for their own rights and freedom ${ }^{22}$. WHO acknowledges the dual burden of disease in the form of disability and care for members of the 
ageing population, and also dependency due to chronic disease, as an important financial cost not only on the health care system, but also for the older adult and his or her family ${ }^{22}$. Overall, in order for older adults to achieve positive health, quality of life and wellbeing, an active approach to ageing is advocated ${ }^{22}$.

Ageing and participation. This theme refers to enjoyable recreational, occupational and psychosocial activities adapted to the older persons' individual preferences, interests and capacities ${ }^{22}$. Low levels of income, loneliness, widowhood and ill-health are all identified as barriers to participation among older adults ${ }^{23}$.

Facilitators or barriers to active ageing. This theme refers to factors that facilitate or hinder active ageing. Two types of barriers can be identified. First, older adults' participation may be hindered by lack of money, living alone and mobility problems, a poor sense of belonging, lack of optimism, trust and poor mental health ${ }^{23}$. Second, negative stereotypes exist towards members of the older generation. Intergenerational activities may soothe some aspects of this negativity and prejudice ${ }^{24}$. With regard to facilitators, the literature points both to the value of both social- and health-related factors. Community-level actions for the prevention of chronic diseases are valuable for older adults ${ }^{22}$. In addition, it is important to take steps to enhance participation, to facilitate prevention and to allow for intergenerational solidarity ${ }^{22}$. Although only a small number of studies show the effects of intergenerational support on health, lifesatisfaction and well-being among older adults, the available evidence signals how intergenerational activities can improve the health status of older adults ${ }^{24,25}$.

\section{Core Theme 2: The Relationship between Social Capital and Ageing}

Socioeconomic inequalities and health. Theories of social capital may be used to understand the relationship between social inequality, poverty and area of residence, health and wellbeing ${ }^{26}$. Social inequalities linked to social isolation and loneliness pose threats to health and wellbeing ${ }^{27}$. Income inequality and poverty are frequently associated with ill-health and, in particular, mental health problems ${ }^{27}$. Low levels of community-level social capital may be associated with higher levels of depression, although the detailed nature of the association has yet to be clarified ${ }^{27}$.

Community participation/social cohesion. Community participation can be viewed both as a determinant and an indicator of social capital, and is linked to self-rated health ${ }^{23}$. In order to be effective, mental health promotion programmes with an emphasis on participation need to be appropriate to the target group.

Religiosity. Religiosity, especially among women, has been associated with good mental health ${ }^{27}$. Participation in religion may provide a coping strategy for loneliness and a shield from stress ${ }^{27}$. Membership of voluntary or religious organizations is associated with better self-rated 
health ${ }^{26}$. Nevertheless, extreme religious communities can cause negative religiosity since they impose on their followers forced social restrictions and moral practice ${ }^{27}$.

Social trust. Among members of the ageing population, good subjective health has been found to be associated with active social participation and trust ${ }^{26}$.

Social networks. Social networks (a core component of social capital), allow for communication at personal, community, and institutional levels. They facilitate the retention of an individual's social identity and enable access to support, both emotional and practical ${ }^{22}$. Communities with high levels of social capital have high levels of social networking, mutual reciprocity, and participation in organizations/groups ${ }^{27}$. Among older adults, lack of social networks has been linked to poor subjective health, while volunteers and people who regularly participate in associations and clubs have been found to report higher levels of wellbeing and better subjective health status ${ }^{26}$.

Social support/loneliness. Loneliness is associated with poorer self-rated health through its impact on health behaviour, stress, and other factors ${ }^{27}$. According to Lauder et al. ${ }^{27}$, a key factor in tackling loneliness is the existence of sufficient forms of social engagement and interaction to meet the need for human closeness. For example, older women who have good friendship networks have been found to have higher levels of self-rated health ${ }^{27}$.

\section{Core Theme 3: The Importance of Social Capital in Health Promotion}

Enhancing community/social participation. In a study by Mendoza-Núñez, et al. ${ }^{22}$, a programme on active ageing for the prevention of chronic diseases among older adults at community level focused on building networks of mutual support between older adults. Another example of an effective multilevel social model of health promotion for older adults is provided by the Experience Corps programme which aimed to strengthen the social capital of older adults through involvement in elementary school settings ${ }^{25}$.

Disease prevention/health care. Mendoza-Núñez et al. ${ }^{22}$ used mutual-help group coordinators, performing actions of self-care to boost older adults' psychological and social well-being in an attempt to prevent the most common diseases within ageing population (e.g. diabetes mellitus, osteoporosis, dementia). Lauder et al. ${ }^{27}$, emphasised the role that community-based nurses can play in improving health and well-being by facilitating the building of effective social networks and thereby enhancing social capital.

Self-actualisation/self-care/mutual-help. Self-actualisation among older people is vital towards active ageing and can be enhanced with self-care and mutual support ${ }^{22}$. 
Family education. Family support can be an important resource for health promotion among an ageing population. One study used General Practititoners to train members of the older person's family on how to provide basic care to older relatives, thereby contributing to illhealth prevention ${ }^{22}$.

Intergenerational support/interaction. As indicated earlier, interaction between members of different generations can have a beneficial impact on ageing populations ${ }^{25}$. In the qualitative study by De Souza ${ }^{24}$, intergenerational interaction programmes were found to enhance trust and reciprocity, which are core components of social capital.

\section{Core Theme 4: Policy Implications}

Challenges for the design and implementation of policies. The recent decrease in birth rates after the 'baby-boom' era in many industralised countries, has led to an increase in the older population, and creates financial and social challenges for the future ${ }^{25}$. Even in developing countries such as Brazil there are major challenges to be faced. Here, economic and social change is reported to have increased the dysfunction of mechanisms that facilitate social integration, and has increased socioeconomic inequality ${ }^{24}$. Problems for the development of interventions for ageing populations include low levels of participation among older adults in training programmes, and the high cost of intensive interventions ${ }^{25}$. The prevention and delay of disability and disease in older adults may lead to reduced ill-health, nevertheless. However, few research and model-based attempts have been made in this direction ${ }^{25}$. On the other hand, programmes have been recently implemented, which may be useful for policy-makers or planners who want to create organizations and institutions that facilitate intergenerational communication and interaction for the benefit of ageing populations ${ }^{25}$.

Community participation-based health promotion . Berry ${ }^{23}$ suggested that increasing community participation can be a relatively inexpensive and cost-efficient way to address issues related to individual trust and loneliness. Loneliness is an issue related to the lack of perceived support, thus, policy-makers could modify public health interventions and services towards tackling loneliness ${ }^{27}$. Further training for community nurses especially regarding mental health interventions, could be important in this regard ${ }^{27}$. Overall, in terms of health promotion, there is need for multilevel interventions, considering both the relations within the social context and individual behaviour ${ }^{25}$.

Active ageing-based health promotion. The current approach to ageing which disregards older adults' potential for social and economic development, and considers them as burden should be substituted by an active ageing model which enables older persons' empowerment through self-care and in this way aims to prevent from ill-health ${ }^{22}$. Towards this goal, community care frameworks need to focus on social support and education if they are to have a significant impact on the quality of life and cost-benefit of the older adults ${ }^{22}$. Active ageing implies a three-dimensional approach: as a paradigm, as a policy framework, and as action at the 
community level ${ }^{22}$. Living longer and healthier also implies facing new challenges in terms of the societal involvement of older adults, who have the opportunity to "give back" to society and remain productive longer; for example, through their paid or voluntary work for the community, and through household and care work for family members ${ }^{25}$.

\section{Discussion}

Based on this literature review/research synthesis, a variety of themes relevant to issues of health promotion, social capital and ageing have emerged. In particular, core themes stress the importance of a) active ageing; b) the relationship between social capital and ageing; $c$ ) the importance of social capital in health promotion; and d) policy implications. In particular, the findings presented here stress the importance of social/community participation for better health, and point to aspects of health promotion relevant to healthy and active ageing.

Papers reviewed suggest that social capital may have a significant role to play in promoting healthy ageing through community participation, although detail is lacking on the precise form that initiatives need to take. Based on findings from the papers reviewed, the following tentative suggestions can be made however. Social capital may be enhanced among the elderly through the following actions: community/social participation by older adults; individual empowerment through self-care; intergenerational and mutual support; the enhancement of social cohesion as a buffer to loneliness; by religious involvement which in some circumstances may increase emotional and mental health; through family education which helps build social trust and social networks around older persons; and through social capital building by nurses involved in disease prevention and control.

The policy implications for health promotion initiatives relevant to ageing and social capital mainly concern the promotion of 'active ageing' in line with the commitments of the European Innovation Partnership on Active and Healthy Ageing which aims to increase the average healthy lifespan by two years by $2020^{28}$. The work of this initiative aims to enhance older persons' social development by facilitating social participation and by providing older people with the opportunity to 'give back' to society by remaining productive in volunteering or paid employment. The need for partnership and multi-disciplinarity action throughout health promotion initiatives aiming at promoting active ageing was also evident from the literature review.

Several challenges need to be overcome however when implementing health promotion initiatives targeting older people. These include public prejudice regarding the usefulness of health promotion strategies implemented in later life; the idea of older people being a burden (rather than an asset) to society; the limited participation of older persons in such training programmes to date; and the cost of such intensive interventions. At a theoretical and research level, there is need to overcome a certain vagueness in notions of social capital and its methodological operation and evaluation, in addition to undertaking more research on the prevention of disease and the reduction of disability for older populations.

With respect to limitations, given the small number of papers available in the literature, this review does not present a comprehensive overview of the topic, since more research is 
needed at an international level. In addition, all the studies reviewed were found to endorse health promotion initiatives for ageing which incorporate social capital theory or component(s) of it. No reference in any of the studies was found to documented disadvantages of health promotion initiatives based on social capital. The inclusion of such negative references, if they exist, would be helpful in identifying the advantages and disadvantages of such an approach and the circumstances in which it is best applied.

Further research might usefully explore the contribution of social capital to addressing the determinants of health, disability and ageing utilising the International Classification of Functioning, Disability and Health (ICF) ${ }^{29}$ 's biopsychosocial model (BPS) for health promotion strategies and research projects and a social ecological approach. Education aiming at building a more positive public perception of ageing should be undertaken since the public prejudice that exists towards older persons seems to hinder the process towards enhancing their health, quality of life and well-being. Such an initiative could contribute at the same time towards the fuller inclusion of persons with disabilities and their families in the community, which is important for social capital building.

\section{Conclusion}

From the current analysis it appears that supporting long-term social capital building within communities may lead towards better health and wellbeing among the ageing population. In the current context of economic crisis, health promotion interventions based on social capital can provide an inexpensive solution for policy-makers, and at the same time provide a holistic means of tackling the forthcoming economic and social changes due to the increase of the ageing population worldwide. Within the present analysis, a wide spectrum of known aspects of the role of social capital in health promotion has been covered. However, further research on the applicability of such initiatives at a practical level should be undertaken to establish the value of this approach in improving the health of specific ageing populations, along with the resolution of theoretical and measurement issues surrounding the notion of social capital and health. 


\section{References}

1. United Nations. World Population Ageing 2009. New York: United Nations;2010. ST/SEA/SER.A/295.

2. World Health Organization. Milestones in Health Promotion: Statements from Global Conferences. Geneva: World Health Organization; 2009.WHO/NMH/CHP/09.01.

3. World Health Organization. The Ottawa Charter for Health Promotion. First International Conference on Health Promotion, Ottawa, 21 November 1986. Geneva: World Health Organization; 1986. . Online. Available:

http://www.who.int/healthpromotion/conferences/previous/ottawa/en/ (accessed 06 April 2011).

4. World Health Organization. Active Ageing: A Policy Framework. Geneva: World Health Organization; 2002. WHO/NMH/NPH/02.8.

5. Laverack G. and Labonte R. A planning framework for community empowerment goals within health promotion. Health Policy and Planning, 2000: 15(3): 255-262.

6. Putnam RD. The Prosperous Community: Social Capital and Public Life. American Prospect; 1993.Online. Available:

http://prospect.org/cs/articles?article=the_prosperous_community\# (accessed 04 April 2011).

7. Howard D, Nieuwenhuusen ER, Saleeby P. Health promotion and education: Application of the ICF in the US and Canada using an ecological perspective. Disability and Rehabilitation, 2008: 30(12-13): 942-954.

8. Fried LP, Carlson MC, Freedman M, Frick KD, Glass TA, Hill J, McGill S, Rebok GW, Seeman T, Tielsch J, Wasik BA, Zeger S. A social model for health promotion for an aging population: Initial evidence on the Experience Corps model. Journal of Urban Health, 2004: 81(1): 64-78.

9. World Health Organization. Preamble to the Constitution of the World Health Organization. International Health Conference, 19 June - 22 July 1946, New York: World Health Organization; 1946.

10. Hansen-Kyle L. A Concept Analysis of Healthy Aging. Nursing Forum, 2005: 40(2): 45-57.

11. European Commission. $\operatorname{COM(2003)~} 650$ final of 30 October 2003. Communication from the Commission to the Council, the European Parliament, the European Economic and Social Committee and the Committee of the regions. Equal opportunities for people with disabilities: A European Action Plan; 2003.

12. Whitelaw S, Baxendale A, Bryce C, MacHardy L, Young I, Witney E. 'Settings' based health promotion: a review. Health Promotion International, 2001: 16(4): 339-353.

13. Poland BD, Green LG, Rootman I. eds. Settings for health promotion: Linking theory and practice. California: Sage Publications, Inc; 2000.

14. Harris N, Grootjans J, Wenham K. Ecological Aging: The Settings Approach in Aged Living and Care Accommodation. EcoHealth, 2008: 5(2): 196-204.

15. Bourdieu P. The forms of capital. In: Richardson J. (ed) Handbook of Theory and Research for the Sociology of Education. New York: Greenwood; 1986, pp.241-258. 
16. Coleman JS. Foundations of Social Theory. Cambridge, Mass.: Harvard University Press; 1990.

17. Gillies P. Effectiveness of alliances and partnerships for health promotion. Health Promotion International, 1998: 13(2): 99-120.

18. Hausman AJ, Becker J, Brawer R. Identifying value indicators and social capital in community health partnerships. Journal of Community Psychology, 2005: 33(6): 691-703.

19. Eriksson M, Dahlgren L, Emmelin M. Understanding the role of social capital for health promotion beyond Putnam: A qualitative case study from northern Sweden. Social Theory \& Health, 2009: 7: 318-338.

20. Nyqvist F, Forsman AK, Giuntoli G, Cattan M. Social capital as a resource for mental wellbeing in older people: A systematic review, Aging \& Mental Health, 2013: 17(4): 394-410.

21. Joffe H. and Yardley L. Content and thematic analysis. In: Marks, D.F. and Yardley, L., eds. Research Methods for Clinical and Health Psychology. London: Sage. Ch. 4; 2004.

22. Mendoza-Núñez VM, Martínez-Maldonado MdeL, Correa-Muñoz E. Implementation of an active aging model in Mexico for prevention and control of chronic diseases in the elderly. BMC Geriatrics, 2009: 9: 40.

23. Berry HL. Social capital elite, excluded participators, busy working parents and aging, participating less: types of community participators and their mental health. Social Psychiatry and Psychiatric Epidemiology, 2008: 43(7): 527-37.

24. De Souza EM. Intergenerational interaction in health promotion: a qualitative study in Brazil. Revista de Saúde Pública, 2003: 37(4): 463-9.

25. Glass TA, Freedman M, Carlson MC, Hill J, Frick KD, lalongo N, McGill S, Rebok GW, Seeman T, Tielsch JM, Wasik BA, Zeger S, Fried LP. Experience Corps: design of an intergenerational program to boost social capital and promote the health of an aging society. Journal of Urban Health, 2004: 81(1): 94-105.

26. Nummela O, Sulander T, Karisto A, Uutela A. Self-rated health and social capital among aging people across the urban-rural dimension. International Journal of Behavioral Medicine, 2009: 16(2): 189-94.

27. Lauder W, Mummery K, Sharkey S. Social capital, age and religiosity in people who are lonely. Journal of Clinical Nursing, 2006: 15(3): 334-40.

28. European Commission. European Innovation Partnership on Active and Healthy Ageing; 2013. Online. Available: http://ec.europa.eu/research/innovationunion/index en.cfm?section=active-healthy-ageing (accessed 18 June 2013).

29. World Health Organization. International Classification of Functioning, Disability and Health. Geneva: World Health Organization; 2001. 
Figure 1. Process of inclusion of studies in the literature review/research synthesis.

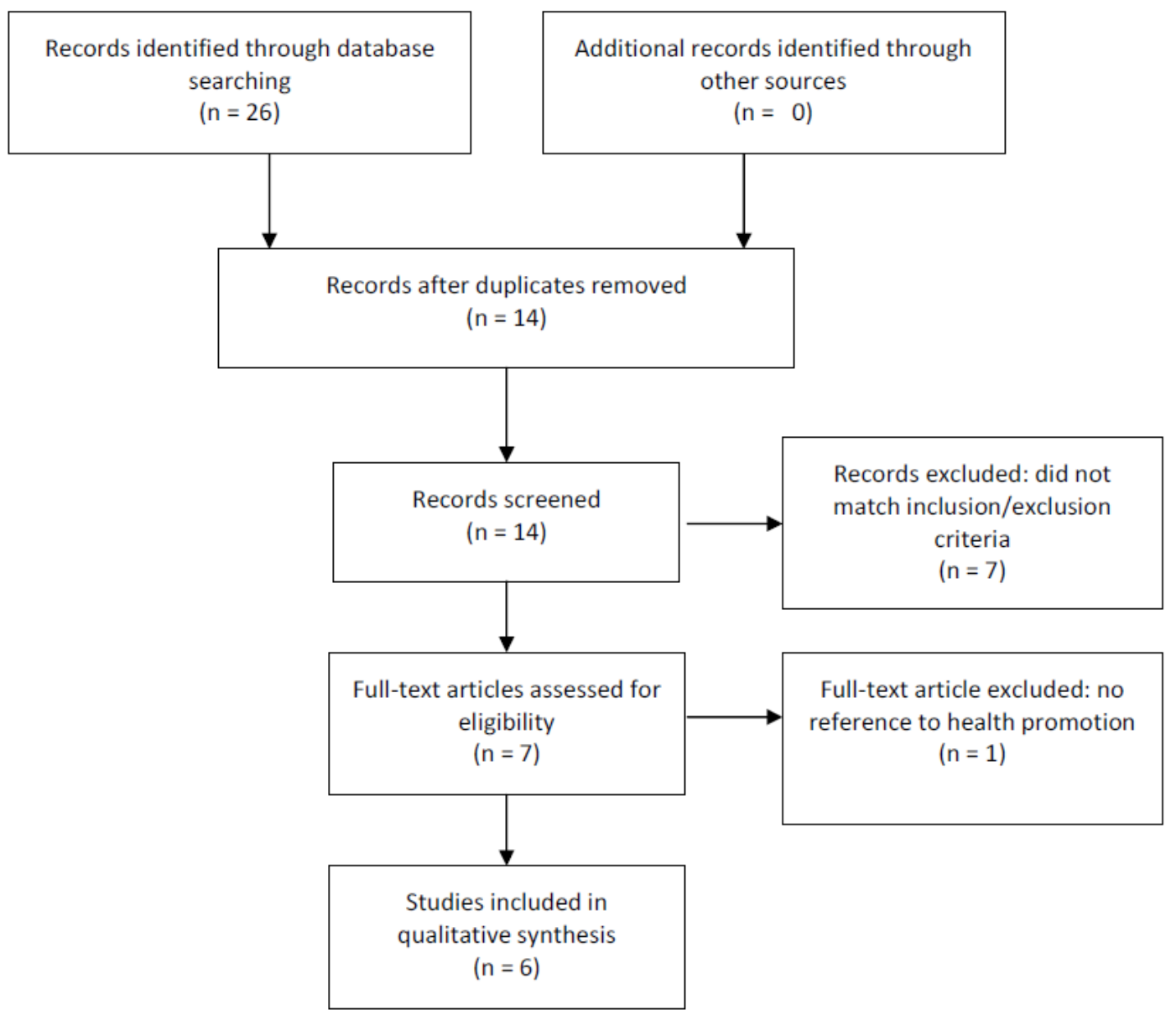


Table 1. List of the studies selected; specific information

\begin{tabular}{|c|c|c|c|c|c|}
\hline $\begin{array}{l}\text { First author, Year } \\
\text { of publication }\end{array}$ & Objective of the study & Method of data collection & Sample and context & $\begin{array}{l}\text { Social capital indicators } \\
\text { used }\end{array}$ & $\begin{array}{l}\text { Health promotion } \\
\text { activities reported }\end{array}$ \\
\hline Berry, H.L., $2008^{23}$ & $\begin{array}{l}\text { To (1) explore whether residents of a } \\
\text { socio-economically disadvantaged } \\
\text { rural Australian region could be } \\
\text { grouped according to their patterns } \\
\text { of community participation, ( } 2 \text { ) } \\
\text { prepare descriptive profiles of these } \\
\text { groupings, (3) report on differences } \\
\text { in social cohesion and psychological } \\
\text { distress between groupings, and (4) } \\
\text { comment on the policy implications } \\
\text { of the groupings. }\end{array}$ & $\begin{array}{l}\text { Quantitative study; } \\
\text { completion of anonymous } \\
\text { postal survey. Measures } \\
\text { included: (1) frequency of } \\
\text { fourteen types of } \\
\text { participation, (2) thoughts } \\
\text { and feelings about each type, } \\
\text { and (3) five aspects of social } \\
\text { cohesion. }\end{array}$ & $\begin{array}{l}\text { Participants were } 963 \\
\text { community members, aged } \\
\text { 19-97, randomly selected } \\
\text { from a socio-economically } \\
\text { disadvantaged coastal } \\
\text { Australian region } \\
\text { (Eurobodalla Shire in } \\
\text { southern coastal New South } \\
\text { Wales, Australia). }\end{array}$ & $\begin{array}{l}\text { Social capital indicators were } \\
\text { used as part of the } \\
\text { Community Participation } \\
\text { Questionnaire, and personal } \\
\text { social cohesion was } \\
\text { measured and defined as } \\
\text { respondents' altruistic values, } \\
\text { sense of belonging, } \\
\text { generalised reciprocity, social } \\
\text { trust and } \\
\text { optimism }\end{array}$ & $\begin{array}{l}\text { Grouping and description } \\
\text { of members of a } \\
\text { socioeconomically } \\
\text { disadvantaged rural } \\
\text { region based on } \\
\text { community participation, } \\
\text { social cohesion and } \\
\text { psychological distress; } \\
\text { reflection on policy } \\
\text { implications }\end{array}$ \\
\hline Glass, T.A., $2004^{25}$ & $\begin{array}{l}\text { To describe a new program } \\
\text { (Experience Corps) which establishes } \\
\text { new, productive roles for older adults } \\
\text { in public elementary schools; these } \\
\text { roles are explicitly designed to boost } \\
\text { the social capital available through } \\
\text { the mobilization of a critical mass of } \\
\text { seniors. This article (1) describes the } \\
\text { scientific basis for this health } \\
\text { promotion intervention, (2) explains } \\
\text { how it simultaneously harnesses the } \\
\text { social capital of an aging society and } \\
\text { seek to "compress" its morbidity, ( } 3 \text { ) } \\
\text { describes the core design features of } \\
\text { Experience Corps, and (4) provides } \\
\text { details about the operational aspects } \\
\text { of the program that support } \\
\text { generativity and social capital. }\end{array}$ & $\begin{array}{l}\text { In essence, the Experience } \\
\text { Corps program involves the } \\
\text { recruitment, training, and } \\
\text { deployment of a critical mass } \\
\text { of older adults who volunteer } \\
\text { their time and experience in } \\
\text { underserved elementary } \\
\text { schools to improve the lives } \\
\text { and academic achievements } \\
\text { of children. The intervention } \\
\text { is hypothesized to operate at } \\
\text { three nested levels: } \\
\text { individuals, schools, and the } \\
\text { broader community. At the } \\
\text { individual level, it proposes a } \\
\text { model based on Erikson's } \\
\text { concept of generativity to } \\
\text { explain how and why } \\
\text { Experience Corps works. At } \\
\text { the level of schools, it } \\
\text { proposes a parallel model } \\
\text { based on social capital. } \\
\text { Experience Corps is a } \\
\text { volunteer service program } \\
\text { designed to improve the lives }\end{array}$ & $\begin{array}{l}\text { Experience Corps volunteers } \\
\text { are predominantly African } \\
\text { American ( } 96 \%) \text { and high- } \\
\text { school educated or less ( } 82 \%) \\
\text { and have incomes of less } \\
\text { than } \$ 15,000(69 \%) \text {. } \\
\text { Participants entered the } \\
\text { program with varying levels } \\
\text { of health and functional } \\
\text { status. Experience Corps } \\
\text { volunteers reported } 2.5 \\
\text { chronic conditions, and most } \\
\text { (62\%) reported some } \\
\text { difficulty climbing stairs. The } \\
\text { program had been expanded } \\
\text { and had been currently } \\
\text { operating in } 18 \text { cities in a } \\
\text { network coordinated through } \\
\text { Civic Ventures. }\end{array}$ & $\begin{array}{l}\text { Social capital is the guiding } \\
\text { theoretical concept at the } \\
\text { school level. The deployment } \\
\text { of a critical mass of older } \\
\text { adults in carefully designed } \\
\text { roles is hypothesized to lead } \\
\text { to improvements in four } \\
\text { primary outcomes: (1) } \\
\text { aggregate academic } \\
\text { achievement (standardized } \\
\text { assessments), (2) overall } \\
\text { school climate, (3) teacher } \\
\text { retention, and (4) } \\
\text { community/parental } \\
\text { involvement in schools. The } \\
\text { program was designed to } \\
\text { have an impact on the entire } \\
\text { school through three } \\
\text { elements: (1) critical mass, (2) } \\
\text { school-level roles performed } \\
\text { outside classrooms, and (3) } \\
\text { adult volunteers who become } \\
\text { conduits to the resources and } \\
\text { concerns of the broader } \\
\text { community. By deploying }\end{array}$ & $\begin{array}{l}\text { Description of conceptual } \\
\text { framework of a model of } \\
\text { health promotion for } \\
\text { older adults to remain } \\
\text { socially engaged and } \\
\text { productive }\end{array}$ \\
\hline
\end{tabular}




\begin{tabular}{|c|c|c|c|c|c|}
\hline & & $\begin{array}{l}\text { of urban children and to yield } \\
\text { health improvement for older } \\
\text { persons. }\end{array}$ & & $\begin{array}{l}\text { volunteers in critical mass, } \\
\text { each becomes an agent of } \\
\text { social capital. }\end{array}$ & \\
\hline Lauder, W., $2006^{27}$ & $\begin{array}{l}\text { The aims of the study were to (i) } \\
\text { investigate age and loneliness, (ii) } \\
\text { investigate the association between } \\
\text { religiosity and loneliness, and (iii) and } \\
\text { explore the relationship between } \\
\text { social capital and loneliness. }\end{array}$ & $\begin{array}{l}\text { The study employed survey } \\
\text { methods of a randomly } \\
\text { selected sample of people } \\
\text { living in Central Queensland, } \\
\text { Australia. Data were collected } \\
\text { by Computer-Assisted } \\
\text { Telephone Interview } \\
\text { methods. In participating } \\
\text { households, one person was } \\
\text { selected as the respondent } \\
\text { for the } 30 \text {-minute interview. }\end{array}$ & $\begin{array}{l}\text { The sample comprised by } \\
1,289 \text { subjects with a mean } \\
\text { age of } 46.25 \text { years (SD 15.61) } \\
\text { of whom } 50.1 \% \text { were female } \\
\text { ( } n=645) \text { and } 49.9 \% \text { male } \\
(n=643) .\end{array}$ & $\begin{array}{l}\text { Social capital was } \\
\text { operationalized through } \\
\text { items selected from the } \\
\text { Social Capital Module of the } \\
\text { General Household Survey } \\
\text { (General Household Survey } \\
\text { 2000). In the General } \\
\text { Household Survey indicators } \\
\text { of social capital are } \\
\text { neighbourliness, civic } \\
\text { engagement, social support, } \\
\text { social networks and } \\
\text { perceptions of the local area. }\end{array}$ & $\begin{array}{l}\text { Investigation of age and } \\
\text { loneliness, religiosity and } \\
\text { loneliness, social capital } \\
\text { and loneliness }\end{array}$ \\
\hline $\begin{array}{l}\text { Mendoza-Núñez } \\
\text { V.M., 2009²2 }\end{array}$ & $\begin{array}{l}\text { To show our experience in the } \\
\text { development and implementation of } \\
\text { a model for chronic disease } \\
\text { prevention and control in old age at } \\
\text { the community level under the active } \\
\text { aging paradigm. }\end{array}$ & $\begin{array}{l}\text { Formation of } 40 \\
\text { gerontological promoters } \\
\text { (GPs) from among the older } \\
\text { adults themselves, following } \\
\text { a specific healthy ageing } \\
\text { model proposed. The pillars } \\
\text { of this model were: } \\
\text { gerontological health care; } \\
\text { gerontological orientation for } \\
\text { families, and gerontological } \\
\text { social development. }\end{array}$ & $\begin{array}{l}\text { A longitudinal study would be } \\
\text { carried out in a sample of } 400 \\
\text { urban and rural-dwelling } \\
\text { older adults residing in } \\
\text { Hidalgo State, Mexico during } \\
\text { five years, with a significance } \\
\text { level of } 0.05 \text {, a power of } 80 \% \\
\text { and an expected difference in } \\
\text { chronic diseases incidence of } \\
50 \% \text { between the pre- } \\
\text { intervention and post- } \\
\text { intervention. Taking into } \\
\text { account a drop-out rate of } \\
30 \% \text { a minimum of } 280 \\
\text { participants would be needed } \\
\text { in the cohort. }\end{array}$ & $\begin{array}{l}\text { Social networks were formed } \\
\text { among older adults based on } \\
\text { self-care, mutual-help, and } \\
\text { self-promotion principles. } \\
\text { Specific workshop community } \\
\text { gerontology topics used } \\
\text { (among many others): Social- } \\
\text { support nets; Leisure and } \\
\text { aging; and Age-related social } \\
\text { changes. }\end{array}$ & $\begin{array}{l}\text { Presentation of } \\
\text { experience on the } \\
\text { development and } \\
\text { implementation of an } \\
\text { active-ageing community- } \\
\text { based framework for } \\
\text { prevention, control, and } \\
\text { empowerment of older } \\
\text { adults regarding chronic } \\
\text { diseases, which } \\
\text { constitutes basic social } \\
\text { capital for chronic disease } \\
\text { prevention and control in } \\
\text { old age. }\end{array}$ \\
\hline $\begin{array}{l}\text { Nummela, O., } \\
2009^{26}\end{array}$ & $\begin{array}{l}\text { To investigate associations between } \\
\text { self-rated health and indicators of } \\
\text { social capital (trust, various social } \\
\text { contacts, social participation, and } \\
\text { access to help) among aging people } \\
\text { living in urban and rural areas in } \\
\text { Finland. }\end{array}$ & $\begin{array}{l}\text { A postal survey was } \\
\text { conducted in } 2002 \text { among } \\
\text { men and women born in } \\
\text { 1926-1930, 1936-1940, or } \\
\text { 1946-1950 and dwelling in } 14 \\
\text { municipalities in the Päijät- } \\
\text { Häme hospital district in } \\
\text { Finland. }\end{array}$ & $\begin{array}{l}\text { A total of } 2,815 \text { participants } \\
\text { represented } 66 \% \text { of the } \\
\text { original stratified (by age, } \\
\text { gender, and municipality) } \\
\text { sample. }\end{array}$ & $\begin{array}{l}\text { Trust; Social contacts with } \\
\text { relatives and family members } \\
\text { (outside households); } \\
\text { Frequency of contacts with } \\
\text { close friends or close } \\
\text { relatives; Participation; } \\
\text { Access to help from other } \\
\text { persons. }\end{array}$ & $\begin{array}{l}\text { Investigation of } \\
\text { associations between self- } \\
\text { rated health and } \\
\text { indicators of social capital } \\
\text { among ageing population }\end{array}$ \\
\hline
\end{tabular}




\begin{tabular}{|l|l|l|l|l|}
\hline de Souza, E.M., & $\begin{array}{l}\text { To evaluate a pilot intergenerational } \\
\text { reminiscence project from the } \\
\text { participants' viewpoint (before and } \\
\text { after the program) and to improve } \\
\text { the contribution of ageing and } \\
\text { adolescent populations in building up } \\
\text { social capital }\end{array}$ & $\begin{array}{l}\text { Qualitative study; focus } \\
\text { groups. During the data } \\
\text { collection process an } \\
\text { interview guide was used } \\
\text { including eight questions (i.e. } \\
\text { "what have you learnt from } \\
\text { the project?", "what is your } \\
\text { opinion about the project?", } \\
\text { "how did the participation in } \\
\text { the project influence your } \\
\text { health?", etc.) }\end{array}$ & $\begin{array}{l}\text { 84 students aged 13-19, } \\
\text { divided into nine focus } \\
\text { groups, plus, 26 older adults } \\
\text { aged 60+, divided into three } \\
\text { focus groups. Focus groups' } \\
\text { sessions took place from } \\
\text { November 1999 to April 2000 } \\
\text { at Taguatinga, Brazil. }\end{array}$ & $\begin{array}{l}\text { No specific social capital } \\
\text { indicators were used for data } \\
\text { collection in this study }\end{array}$ \\
& & $\begin{array}{l}\text { Evaluation of pilot project } \\
\text { for promoting well-being } \\
\text { of ageing and adolescent } \\
\text { populations through } \\
\text { intergenerational activity } \\
\text { and improvement of the } \\
\text { contribution of these age } \\
\text { groups in building social } \\
\text { capital }\end{array}$ \\
\hline
\end{tabular}


Table 2. List of the themes that emerged from the current analysis.

\begin{tabular}{l} 
Core Theme 1: Active Ageing \\
Defining Active Ageing \\
Ageing and participation \\
Facilitators or Barriers to Active Ageing \\
\hline Core Theme 2: The Relationship between Social Capital and Ageing \\
Socioeconomic inequalities and health \\
Community participation / Social cohesion \\
Religiosity \\
Social trust \\
Social networks \\
Social support / Loneliness \\
\hline Core Theme 3: The Importance of Social Capital in Health Promotion \\
Enhancing community / social participation \\
Disease prevention / Health care \\
Self-actualisation / Self-care / Mutual-help \\
Family education \\
Intergenerational support / interaction \\
\hline Core Theme 4: Policy Implications \\
Challenges for the design and implementation of policies \\
Community participation-based health promotion \\
Active ageing-based health promotion
\end{tabular}

